have a post-ROSC ECG demonstrating ST elevation/LBBB and absence of epinephrine administration during resuscitation with shorter low flow times. Extent of CAD was similar between the four groups. From patients with $\operatorname{LVEF} \geq 40 \%$, patients in Group C had substantially lower SYNTAX scores than compared with Group D $(0.5$ vs $13.5, \mathrm{p}<0.001)$. However, both Group B and C (RWMA) groups had highest rates of culprit lesions compared with matched global groups which was reflected in higher PCI rates (figure 2 and table 3). The primary endpoint of 12-month mortality was lowest in Group D and highest in the Group A group. A similar effect was observed for poor neurological outcome and 30-day mortality. Patients with regional LVSD had significantly improved survival at 12 months compared with those with global LVSD $(70.5 \%$ vs $48.3 \%, \mathrm{p}<0.001)$ vs 51$)$. Those in Group D had

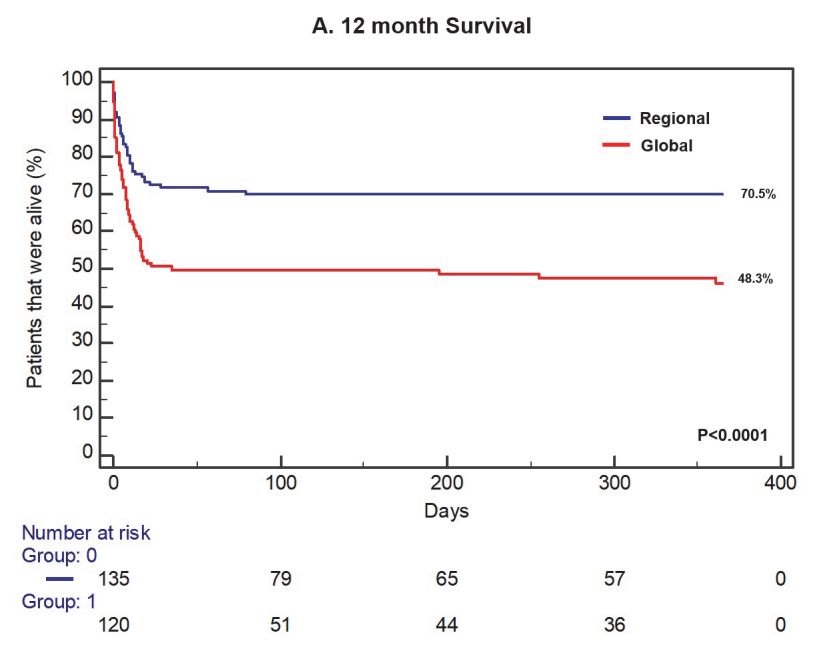

Abstract 42 Figure 2

Abstract 42 Table 1 Baseline Characteristics by Presence of RWMAs and Initial LV Systolic Function

\begin{tabular}{|c|c|c|c|c|c|c|}
\hline & \multicolumn{3}{|l|}{ LVEF $<40 \%$} & \multicolumn{3}{|l|}{ LVEF $\geq 40 \%$} \\
\hline & RWMAs & No RWMAs & $P$ & RWMAs & No RWMAs & $P$ \\
\hline & $N=29$ & $\mathrm{~N}=67$ & value & $N=110$ & $\mathrm{~N}=60$ & value \\
\hline & 3 & 4 & & 1 & 2 & \\
\hline Age & $61(54-66)$ & $67(59-75)$ & 0.009 & $60(51-69)$ & $62(48-70)$ & 0.982 \\
\hline Male (\%) & $25(86.2 \%)$ & $53(79.1 \%)$ & 0.413 & $87(79.1 \%)$ & $38(63.3 \%)$ & 0.026 \\
\hline Witnessed & $23(79.3 \%)$ & $58(86.6 \%)$ & 0.369 & $91(82.7 \%)$ & $50(83.3 \%)$ & 0.920 \\
\hline Residence & $17(58.6 \%)$ & $35(52.2 \%)$ & 0.564 & $53(48.2 \%)$ & $33(55.0 \%)$ & 0.395 \\
\hline \multicolumn{7}{|l|}{ Location } \\
\hline Bystander & $20(69.0 \%)$ & $48(71.6 \%)$ & 0.791 & $85(77.3 \%)$ & $48(80.1 \%)$ & 0.680 \\
\hline \multicolumn{7}{|l|}{ CPR } \\
\hline Low Flow & 25.5 & $28(17.5-40)$ & 0.238 & $19(9-28)$ & 25 (17.5- & 0.008 \\
\hline Time & $36.25)$ & & & & 33.5) & \\
\hline VF/VT & $22(75.9 \%)$ & $54(80.6 \%)$ & 0.600 & $93(84.5 \%)$ & 47 (78.3\%) & 0.310 \\
\hline Epinephrine & 17 (58.6\%) & 57 (85.1\%) & 0.005 & 55 (50.9\%) & 40 & 0.049 \\
\hline use & & & & & $(66.7 \%)$ & \\
\hline \multirow[t]{2}{*}{$\mathrm{pH}$} & 7.24 (7.17- & 7.21 (7.05- & 0.553 & 7.28 (7.20- & 7.22 (7.1- & 0.017 \\
\hline & 7.32) & 7.29) & & 7.35) & 7.32) & \\
\hline \multirow[t]{2}{*}{ Lactate } & $4.6(2.7-6.6)$ & $4.8(2.5-9.3)$ & 0.828 & 3.1 (1.7- & 4.8 (2.3- & 0.031 \\
\hline & & & & 5.8) & 7.4) & \\
\hline
\end{tabular}

HTN, hypertension; CPR, cardiopulmonary resuscitation; VFIVT, ventricular fibrillation/ventricular tachycardia
Abstract 42 Table 2 Admission and Outcome Metrics by Presence of Regional Wall Motion Abnormalities (RWMAs) and LV Systolic Function on Initial Transthoracic Echocardiography

\begin{tabular}{|c|c|c|c|c|c|c|}
\hline & \multicolumn{3}{|c|}{ LVEF $<40 \%$} & \multicolumn{3}{|c|}{ LVEF $\geq 40 \%$} \\
\hline & $\begin{array}{l}\text { RWMAs } \\
\mathrm{N}=29\end{array}$ & $\begin{array}{l}\text { No RWMAs } \\
N=67\end{array}$ & $\begin{array}{l}\mathrm{P} \\
\text { Value }\end{array}$ & $\begin{array}{l}\text { RWMAs } \\
\mathrm{N}=110\end{array}$ & $\begin{array}{l}\text { No } \\
\text { RWMAs } \\
\mathrm{N}=60\end{array}$ & $\begin{array}{l}P \\
\text { Value }\end{array}$ \\
\hline ST Elevation/LBBB & $\begin{array}{l}26 \\
(89.7 \%)\end{array}$ & 47 (70.1\%) & 0.039 & $\begin{array}{l}83 \\
(75.5 \%)\end{array}$ & $\begin{array}{l}25 \\
(41.7 \%)\end{array}$ & $<0.001$ \\
\hline LVEF (median, IQR) & $\begin{array}{l}30(30- \\
35)\end{array}$ & $30(30-30)$ & 0.002 & $\begin{array}{l}45(40- \\
50)\end{array}$ & $\begin{array}{l}55(45- \\
55)\end{array}$ & $<0.001$ \\
\hline Culprit lesion & $\begin{array}{l}25 \\
(86.2 \%)\end{array}$ & $32(47.8 \%)$ & $<0.001$ & $\begin{array}{l}91 \\
(82.7 \%)\end{array}$ & $\begin{array}{l}26 \\
(43.3 \%)\end{array}$ & $<0.001$ \\
\hline $\mathrm{PCl}$ & $\begin{array}{l}25 \\
(86.2 \%)\end{array}$ & $28(41.8 \%)$ & $<0.001$ & $88(80 \%)$ & $\begin{array}{l}25 \\
(41.7 \%)\end{array}$ & $<0.001$ \\
\hline SYNTAX score & $\begin{array}{l}19(9- \\
26.5)\end{array}$ & $15.5(0-28)$ & 0.332 & $\begin{array}{l}13.5(7- \\
21.5)\end{array}$ & $\begin{array}{l}0.5(0- \\
12)\end{array}$ & $<0.001$ \\
\hline SCAI C-E & $\begin{array}{l}18 \\
(62.1 \%)\end{array}$ & $44(66.7 \%)$ & 0.665 & $\begin{array}{l}35 \\
(32.4 \%)\end{array}$ & $\begin{array}{l}23 \\
(38.3 \%)\end{array}$ & 0.439 \\
\hline 12 month mortality & $\begin{array}{l}14 \\
(48.3 \%)\end{array}$ & $39(58.2 \%)$ & 0.369 & $\begin{array}{l}27 \\
(24.5 \%)\end{array}$ & $\begin{array}{l}27 \\
(45 \%)\end{array}$ & 0.006 \\
\hline 30 day mortality & $\begin{array}{l}14 \\
(48.3 \%)\end{array}$ & $37(55.2 \%)$ & 0.531 & $\begin{array}{l}25 \\
(22.7 \%)\end{array}$ & $\begin{array}{l}26 \\
(43.3 \%)\end{array}$ & 0.005 \\
\hline Cardiac Death & $\begin{array}{l}5 / 14 \\
(35.7 \%)\end{array}$ & $\begin{array}{l}10 / 41 \\
(24.4 \%)\end{array}$ & 0.411 & $\begin{array}{l}1 / 29 \\
(3.4 \%)\end{array}$ & $\begin{array}{l}2 / 28 \\
(7.1 \%)\end{array}$ & 0.532 \\
\hline $\begin{array}{l}\text { Poor Neurological } \\
\text { Outcome }\end{array}$ & $\begin{array}{l}14 \\
(48.3 \%)\end{array}$ & $46(68.7 \%)$ & 0.058 & $\begin{array}{l}37 \\
(33.6 \%)\end{array}$ & $\begin{array}{l}31 \\
(51.7 \%)\end{array}$ & 0.022 \\
\hline
\end{tabular}

highest survival at 12 months, while this was similar for Groups B and C and lowest in Group A (figure 1). Cardiac aetiology death was significantly higher in those with LVEF $<40 \%$ compared to those with $\mathrm{LVEF} \geq 40 \%(70.5 \%$ vs $48.3 \%, \mathrm{p}<0.001)$.

Conclusions Patients with significant LVEF $<40 \%$ have higher rates of cardiogenic shock and mortality which was driven by cardiac aetiology death, while presence of RWMAs are associated with a higher rate of culprit coronary lesions and improved outcome

Conflict of Interest None

\section{ST-ELEVATION MYOCARDIAL INFARCTION IN SUB- SAHARAN AFRICA: THE NEED FOR BETTER DATA}

Jonathan Hudson. London School of Hygiene \& Tropical Medicine, London, UK

\subsection{6/heartjnl-2021-BCS.43}

Introduction There is growing evidence that cardiovascular disease (CVD) prevalence is increasing in Sub-Saharan Africa (SSA) (1). Historically the prevalence of MI in SSA has been thought to be low (2). However, this may be changing as parts of SSA undergo urbanization, and the rates of CVD increase(1), there is a growing awareness of the need to have health systems in place that can manage a time-sensitive cardiovascular emergency like STEMI. The acute management of STEMI presents significant challenges to health systems in SSA. A systematic review was conducted to explore the 
outcomes and rates of emergency coronary reperfusion therapy in adult patients with STEMI in SSA.

Methods A literature search of two databases (MEDLINE \& EMBASE) was performed up to March 1st, 2021 around the keywords 'ST-segment elevation myocardial infarction' and 'Sub-saharan Africa'. Studies were included if they were performed in SSA and reported the in-hospital mortality and emergency management of patients with STEMI. The quality of the studies was appraised using a structured checklist. All analyses were performed using STATA. The Freeman-Turkey double arcsine transformation was used to pool the data by random-effects meta-analysis. This produced a pooled prevalence of in-hospital mortality in patients with STEMI. Heterogeneity between the studies was assessed using the I2 measure. Results Study selection: A total of 12 studies from six different countries were included in the final analysis. 1096 records were retrieved from the database search and screened. 30 full texts were retrieved for consideration. STEMI outcomes: A total of 2279 patients with STEMI were included across 12 studies (table $1 \&$ table 2 ). The pooled in-hospital mortality was $12.8 \%$ (95\% CI $8.41,17.92)$ (figure 1). When stratified by income level of the country (figure 2), STEMI in-hospital mortality decreases as income level increases (Low-income countries $(\mathrm{LIC})=17.79 \%$ [95\% CI 9.16,28.39]), lower middle-income countries $(\mathrm{LMIC})=11.28 \%$ [95\% CI 6.91, 16.50], upper middle income $(\mathrm{UMIC})=5.4 \%[95 \%$ CI 3.62, 7.97]). The pooled proportion of STEMI patients receiving emergency coronary reperfusion was $29.54 \%$ (CI 11.65, 51.11) (Fig2). Thrombolysis was the most common reperfusion therapy used. Primary PCI was rarely used as the method of coronary reperfusion with only 87 patients receiving it across all studies. Significant delays in presentation to hospital may be contributing to poor outcomes (table 2). In Burkina Faso, the average time from onset of symptoms to admission was $48 \mathrm{hrs}$ with $82 \%$ arriving $>12 \mathrm{hrs}$ after symptoms onset. Two studies from Ethiopia reported an average time from onset of symptoms to admission of $>90 \mathrm{hrs}$.

Conclusion This systematic review demonstrates high variability in the management and outcomes of patients with STEMI in SSA and has three key findings. First, the pooled in-hospital mortality of patients with STEMI in SSA is high, at $12.8 \%$. Second, a low proportion of patients with STEMI receive emergency coronary reperfusion. Thirdly, for patients with STEMI, there exist long delays between symptom onset and

Abstract 43 Table 1 Baseline characteristics of studies included. CS= cross sectional study. L1 low income, LMI low middle Income, UMfr upper middle income

\begin{tabular}{|c|c|c|c|c|c|c|c|c|c|c|c|c|}
\hline Author & Country & $\begin{array}{l}\text { Income } \\
\text { Level of } \\
\text { country }\end{array}$ & $\begin{array}{l}\text { Design of } \\
\text { study }\end{array}$ & $\begin{array}{l}\text { Type of } \\
\text { hospital }\end{array}$ & Department & $\begin{array}{c}\text { PCI } \\
\text { capacity? }\end{array}$ & From & To & $\begin{array}{c}\begin{array}{c}\text { Mean } \\
\text { age }\end{array} \\
\end{array}$ & \% Men & $\begin{array}{c}\text { Total } \\
\text { number of } \\
\text { patients in } \\
\text { study }\end{array}$ & $\begin{array}{l}\text { no. of patients } \\
\text { with STEMI in the } \\
\text { study }\end{array}$ \\
\hline Desta et al. 2020 (3) & Ethiopia & $\mathrm{LI}$ & cs & Tertiary & Cardiology & Yes & 2013 & 2018 & 59 & 72.2 & 151 & 110 \\
\hline Beyers et al. 2020 (4) & South Africa & UMI & cs & Tertiary & $\begin{array}{l}\text { Cardiology } \\
\end{array}$ & Yes & 2017 & 2018 & 56 & 66.1 & 447 & 426 \\
\hline Yao et al. 2019 (5) & Ivory Coast & LMI & Prospective & Tertiary & ICU & Yes & 2012 & 2015 & 57 & 82.6 & 329 & 329 \\
\hline Bogale et al. $209(6)$ & Ethiopia & LI & CS & Tertiary & Cardiology & No & 2012 & 2014 & 56.3 & 75.8 & 124 & 90 \\
\hline Kabore 2019 (7) & $\begin{array}{c}\text { Burkina } \\
\text { Faso }\end{array}$ & $\mathrm{LI}$ & Prospective & Tertiary & Cardiology & No & 2010 & 2015 & 57.6 & 77.5 & 111 & 98 \\
\hline Varwani 2019 (8) & Kenya & LMI & CS & Tertiary & Cardiology & Yes & 2012 & 2013 & 58.7 & 81.2 & 230 & 101 \\
\hline Bahiru 2018 (9) & Kenya & LMI & cs & Tertiary & Cardiology & Yes & 2013 & 2016 & 57 & 65 & 196 & 112 \\
\hline Pessinaba $2018(10)$ & Togo & LI & Prospective & Tertiary & $\begin{array}{l}\text { Cardiology } \\
\end{array}$ & No & 2014 & 2017 & 60 & 65.7 & 67 & 48 \\
\hline $\begin{array}{l}\begin{array}{l}N \text { 'Guetta et al. } 2016 \\
\text { (11) }\end{array} \\
\end{array}$ & Ivory Coast & LMI & Prospective & Tertiary & Cardiology & Yes & 2010 & 2013 & \begin{tabular}{|c|c|}
55.4 & \\
\end{tabular} & 79.5 & 425 & 304 \\
\hline Wachira 2013 (12) & Kenya & LMI & CS & Tertiary & cardiology & Yes & 2012 & 2013 & 59.7 & 82 & 45 & 45 \\
\hline $\begin{array}{l}\text { Shavadia et al. } 2012 \\
\text { (13) }\end{array}$ & Kenya & LMI & Prospective & Tertiary & ICU & Yes & 2008 & 2010 & 63 & 82 & 111 & 62 \\
\hline Yameogo 2012 (14) & $\begin{array}{l}\text { Burkina } \\
\text { Faso }\end{array}$ & $\mathrm{LI}$ & Prospective & Tertiary & Cardiology & No & 2010 & 2011 & 56 & 88.4 & 43 & 43 \\
\hline
\end{tabular}

Abstract 43 Table 2 In-hospital mortality of patients with STEMI, coronary reperfusion rates, and delays

\begin{tabular}{|c|c|c|c|c|c|c|}
\hline \multirow[b]{2}{*}{ Study \& Country } & \multirow[b]{2}{*}{$\begin{array}{l}\text { In Hospital STEMI } \\
\text { mortality n/N (\%) }\end{array}$} & \multicolumn{3}{|c|}{ Coronary Reperfusion therapy } & \multicolumn{2}{|r|}{ Delays in presentation } \\
\hline & & $\begin{array}{c}\text { No. patients } \\
\text { receiving } \\
\text { thrombolysis }\end{array}$ & $\begin{array}{l}\text { No. patients } \\
\text { receiving } \\
\text { primary PCI }\end{array}$ & $\begin{array}{l}\text { No. of patients receiving } \\
\text { emergency coronary } \\
\text { reperfusion } n / N(\%)\end{array}$ & $\begin{array}{l}\text { Reported } \\
\text { delay }\end{array}$ & Metric used to report delay \\
\hline Desta 2020 Ethiopia (3) & $25 / 110(22.7)$ & 7 & 6 & $13 / 110(11.82)$ & $95.85 \mathrm{hrs}$ & $\begin{array}{l}\text { Average time from onset of } \\
\text { symptoms to admission }\end{array}$ \\
\hline $\begin{array}{l}\text { Beyers } 2020 \text { South } \\
\text { Africa (4) }\end{array}$ & $23 / 426(5.4)$ & 318 & 0 & $318 / 426(74.6)$ & 5.5hrs & $\begin{array}{l}\text { Median time between symptoms } \\
\text { onset and fibrinolysis }\end{array}$ \\
\hline $\begin{array}{l}\text { Yao } 2019 \text { Ivory Coast } \\
\text { (5) }\end{array}$ & $47 / 329(14.2)$ & 10 & 17 & $27 / 329(8.2)$ & $20.0 \mathrm{hrs}$ & $\begin{array}{l}\text { Median time between onset of } \\
\text { symptoms and admission }\end{array}$ \\
\hline $\begin{array}{l}\text { Bogale } 2019 \text { Ethiopia } \\
\text { (6) }\end{array}$ & $32 / 90(35.6)$ & 0 & 0 & $0 / 90(0)$ & 91.2hrs & $\begin{array}{l}\text { Median time between onset of } \\
\text { symptoms and admission }\end{array}$ \\
\hline $\begin{array}{l}\text { Kabore } 2019 \text { Burkina } \\
\text { Faso (7) }\end{array}$ & 9/98 (9.2) & 8 & 0 & $8 / 98(8.2)$ & $82.9 \%$ & $\begin{array}{c}\% \text { of patients presenting }>12 \mathrm{hrs} \text { from } \\
\text { symptom onset }\end{array}$ \\
\hline $\begin{array}{l}\text { Varwani } 2019 \text { Kenya } \\
\text { (8) }\end{array}$ & $15 / 101(14.9)$ & 49 & 19 & $68 / 101(67.3)$ & $>12 \mathrm{hrs}$ & $\begin{array}{l}\text { Median time between symptoms } \\
\text { onset and admission }\end{array}$ \\
\hline Bahiru 2018 Kenya (9) & $23 / 112(20.4)$ & 2 & 0 & $2 / 112(1.8)$ & $\begin{array}{c}\text { Not } \\
\text { reported }\end{array}$ & \\
\hline $\begin{array}{l}\text { Pessinaba } 2018 \text { Togo } \\
\text { (10) }\end{array}$ & $6 / 48(12.5)$ & 7 & 0 & $7 / 48(14.6)$ & 81.9hrs & $\begin{array}{l}\text { Average time from onset of } \\
\text { symptoms to admission }\end{array}$ \\
\hline $\begin{array}{l}\text { N'Guetta } 2016 \text { Ivory } \\
\text { Coast (11) }\end{array}$ & $34 / 304(11.2)$ & 25 & 20 & $45 / 304(14.8)$ & $44.7 \mathrm{hrs}$ & $\begin{array}{l}\text { Average time from onset of } \\
\text { symptoms to admission }\end{array}$ \\
\hline $\begin{array}{l}\text { Wachira } 2013 \text { Kenya } \\
\text { (12) }\end{array}$ & $0 / 45(0)$ & 28 & 17 & $45 / 45(100)$ & $22 \%$ & $\begin{array}{l}\% \text { of patients presenting }>12 \mathrm{hrs} \text { from } \\
\text { symptom onset }\end{array}$ \\
\hline $\begin{array}{l}\text { Shavadia } 2012 \text { Kenya } \\
\text { (13) }\end{array}$ & $6 / 62(9.7)$ & 34 & 8 & $42 / 62(67.7)$ & $12.9 \mathrm{hrs}$ & $\begin{array}{l}\text { Average time from onset of } \\
\text { symptoms to admission }\end{array}$ \\
\hline $\begin{array}{l}\text { Yameogo } 2012 \text { Burkina } \\
\text { Faso (14) }\end{array}$ & $5 / 43(11.6)$ & 2 & 0 & $2 / 43(4.7)$ & $48 \mathrm{hrs}$ & $\begin{array}{l}\text { Average time from onset of } \\
\text { symptoms to admission }\end{array}$ \\
\hline
\end{tabular}




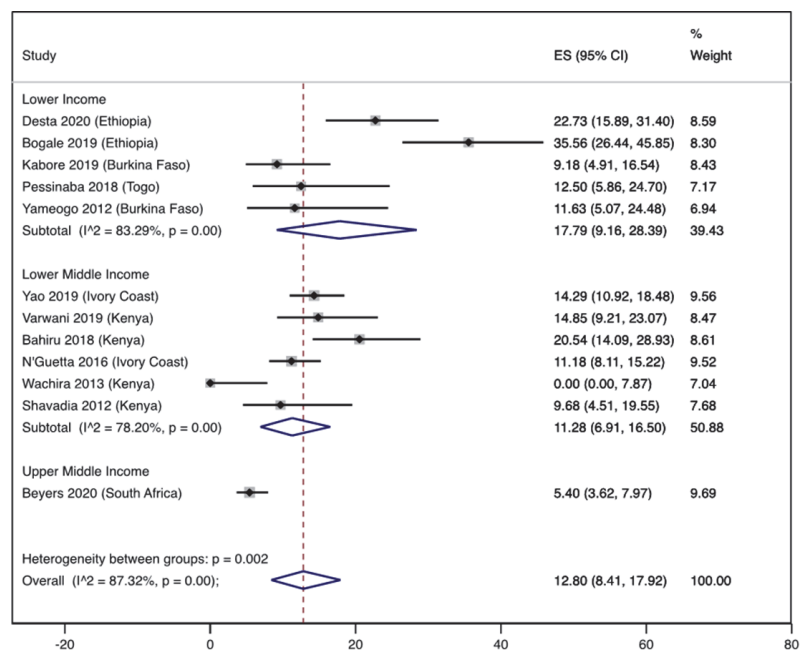

Abstract 43 Figure 1 In hospital mortality of patients with STEMI stratified by income level of country. Effect Size (ES) is the \% of patients with STEMI who died in hospital

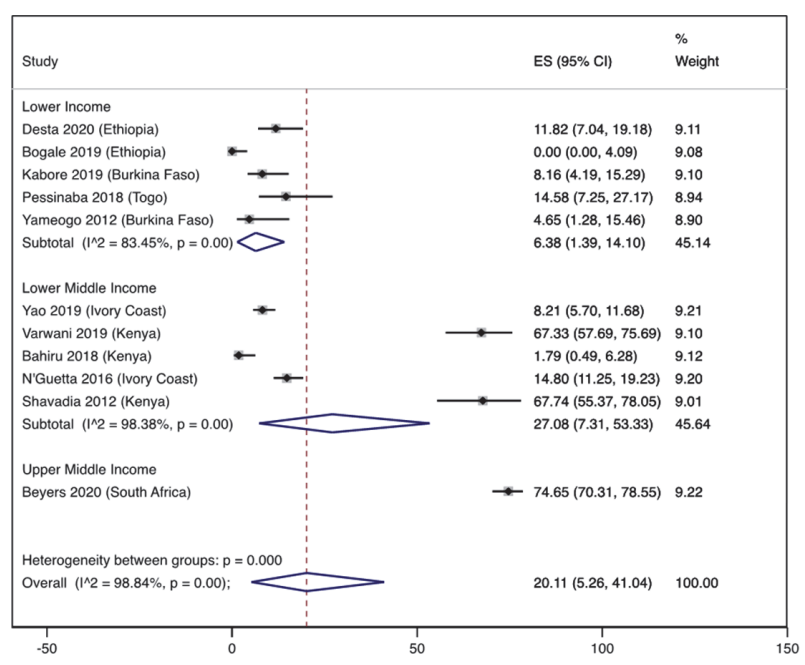

Abstract 43 Figure 2 Meto-anal ysis of the proportion of patients with STEMI who received emergency coronary reperfusion (either $\mathrm{PCl}$ or thrombolysis) stratified by country income level

presentation to hospital. This is the first meta-analysis attempting to pool the in-hospital mortality and emergency treatment of patients with STEMI in SSA. The studies included were of moderate to poor quality and suffered from small sample sizes. As the burden of IHD increases in SSA, health systems must adapt to be able to produce better outcomes for patients presenting with STEMI.

Conflict of Interest None

\section{IDENTIFYING LOW-RISK RISK CHEST PAIN IN THE EMERGENCY DEPARTMENT WITHOUT TROPONIN TESTING: A VALIDATION STUDY OF THE HE-MACS AND HEAR RISK SCORES}

Fraser Todd, James Duff, Ed Carlton. North Bristol Trust, Bristol, UK

10.1136/heartjnl-2021-BCS.44
Introduction Patients presenting to Emergency Departments with chest pain of possible cardiac origin represent a substantial and challenging cohort to risk stratify. Scores such as HEMACS (History and Electrocardiogram-only Manchester Acute Coronary Syndromes decision aid) and HEAR (History, ECG, Age, Risk factors) have been developed to stratify risk without the need for troponin testing. Validation of these scores remains limited at present.

Methods We performed a post-hoc analysis of the LoDED (Limit of Detection and ECG discharge strategy) randomisedcontrolled trial dataset. Data collected during the trial, and prior to troponin results, were used to calculate HEAR and HE-MACS scores. Previously published thresholds of $<4 \%$ for HE-MACS and $<2$ for HEAR defined very low risk patients. The primary outcome of MACE (major adverse cardiac events) at 30 days was used to assess diagnostic accuracy.

Results 629 patients were included, with a 7\% (42/629) incidence of MACE within 30 days. HE-MACS and HEAR scores identified $85 / 629$ and $181 / 629$ patients predicted to be at very low risk of MACE. Within these cohorts, MACE occurred in $0 / 85$ and $1 / 181$ patients respectively. Sensitivity of HE-MACS and HEAR were 100\% (95\% CI: 91.6-100\%) and 97.6\% (95\% CI: 87.7-99.9\%) respectively. Receiver operating characteristic (ROC) curves demonstrated area under curve (AUC) of 0.80 [95\%CI: 0.74-0.85] for HE-MACS and 0.76 [95\% CI: 0.69-0.82] for HEAR.

Conclusion HEAR and HE-MACS show potential as rule out tools for acute myocardial infarction without the need for troponin testing. However, prospective studies are required to further validate these scores for clinical implementation.

Conflict of Interest None declared

\section{COMPLETE REVASCULARISATION IS ASSOCIATED WITH IMPROVED SURVIVAL AFTER OUT OF HOSPITAL CARDIAC ARREST}

Ritesh Kanyal, Nilesh Pareek, Dhruv Sarma, Apurva Bharucha, Rafal Dworakowski, Narbeh Melikian, Ian Webb, Ajay Shah, Philip MacCarthy, Jonathan Byrne. King's College Hospital, London, UK

\subsection{6/heartjnl-2021-BCS.45}

Introduction Coronary artery disease (CAD) is common in patients with Out of Hospital Cardiac Arrest (OOHCA) but the clinical relevance of burden of $\mathrm{CAD}$ and evidence for revascularisation strategies in relation to outcomes and modes of death remains unclear. This study sought to assess the extent of CAD as defined by the SYNTAX score and prognostic value of complete compared with incomplete revascularisation by evaluating the SYNTAX revascularisation index (SRI) in patients with OOHCA.

Methods 619 patients with OOHCA were admitted at our centre between 1st May 2012 and 31st December 2017. 237 were excluded for having a non-cardiac aetiology or prior neurological disability. 398 patients were included into the study and of these 272 (xx\%) had early coronary angiography and were included in the final analysis. The baseline SYNTAX score (bSS) and residual SYNTAX score (rSS) were determined from the coronary angiograms by a blinded cardiologist. Patients were subdivided into 4 subgroups according to quartiles of the baseline syntax score (bSS) of 0, Group A: 1-10, Group B: $11-20$ and Group C: $\geq 21$. Complete 